\title{
The Necessity of Dialectical Naturalism: Marcuse, Bookchin and dialectics in the midst of ecological crises
}

“... the environmental crisis involves a crisis of the imagination the amelioration of which depends on finding better ways of imagining nature and humanity’s relation to it.”

- Lawrence Buell (1995: 2)

\section{Introduction}

Central to dialectics is its account of totality, the historical (temporal), environmental (spatial) and social (cultural) whole. For it is in this totality - that expansive concept of the whole and all its parts - that the complex interactions, tensions and contradictions that generate transformation, take place. As such, how dialectical approaches understand and conceive of the totality takes on acute ontological significance and function. Dialectical analysis, then, requires the utmost precision to ensure its ontological postulates (interconnectivity, contradiction, negation, sublation, flux, amongst others) are directly reflected in how it accounts for the temporal, spatial and cultural context in which transformations take place. For dialectical approaches, context is much more than the environmental and geographical conditions pertaining to the phenomena under analysis, it also embodies the interstitial situatedeness in which humans relate intersubjectively, and the far more expansive notion of how we conceive of nature as a totality (inclusive of all human communities, biological life and earth-systems), and thereby come to understand contradictions within this dynamic whole taken as society and nature, or what we call in this paper the 'human and nature affinity'. Yet even the most famous proponents of dialectics in modern thought, Hegel and Marx, expressed only a limited appreciation of the relational affinity of human and nature, or how subject and its surrounding object, relate dialectically. Hegel saw nature as a "living whole" and yet an expanse in which there was no freedom, “only necessity and contingency” (2004: § 195, § 193). For him, Nature’s highest point was the animal organism passing into subjectivity and into 'Spirit', thereby setting humanity (and Mind) in separation from Nature that remained object, only (Hegel, 2004: § 298). For the mature Hegel, 'anthropology' designates a purely negative state of "the soul in its uncultivated 
natural condition” (Hegel, 2007: 81). The complementarity between humanity and its surrounding geography is thus posited as the purely Fichtean negative unity of the Ego superseding its other: "the goal of the natural soul is liberation from this uncultivated natural condition; in freedom it becomes I, the free being at home with itself of spirit” (Hegel, 2007: 81). Similarly, Marx's entreatment to naturalism as humanism appreciated Nature as the basis of human intelligence and capacity, or 'species-life'. Whilst this widened the scope of human relations with nature, it did so in such a way that emphasised material activity on, or over, nature, and in which Nature tended to recede to a mere passive object (Marx \& Engels, 1975 Part I, A, 4). Of course, Marx brought to the fore that humanity is formed by the totality of social relations, of which nature is integral, and emphasized these as specific, historical and transient conditions that humankind is an active part in shaping (Marx, 1969: 13-15). But the tendency toward objectifying this process as one of determinism rather than active conditioning begun by Engels (1972: esp. 54) and dogmatized under Diamat, meant that Marxism lost any sensibility of the fundamental affinity between human and nature. Arguably it is only in Adorno that we find a serious attempt to overcome this split of the subject and object in philosophy through dialectics, and yet even this is not brought to bare on the question of the human and nature relation but was expressed as a problem of historical experience (see 1998).

In this article, we contest this troubling split of humanity from nature - and the reification of the former as something apart from its natural environs - in dialectical thought. This is not a mere critique of anti-naturalistic bias across the political 'sciences', but rather to demonstrate that the lack of recognition of the fundamental relation between humanity and nature has rendered dialectical thought unable to achieve a genuine understanding of the 'whole'. Theoretical choices do not necessarily determine political commitments, but they do open possibilities and close off others. Consequently, it is only in moving toward a dialectical account of the totality that is necessarily inclusive of the situatedness of humanity in nature, and of nature in humanity, that we can begin to grapple with the accelerating ecological crises of the present.

Dialectics has been a "steady presence” in radical geography, appearing notably in Antipode from 1969 onwards, and is a concept that appears an average of six times annually in geographical journals (Sheppard, 2008: 2603). Only recently has the question of the human and nature relation become a common thematic. For example, a leading figure in dialectical 
geography up into the late 1970s was Bernard Marchan whose analysis built upon a certain Hegelian and anachronistic reading of the Frankfurt School’s account of dialectics (1979: 237ff). His version was premised on an over-determined notion of the Fichtean dialectical 'triad' ('thesis, antithesis and synthesis') that implied the primary determination of nature was space i.e. the property of self-externality. While he railed against immediacy that separated subject and object, by restricting the former to merely mirroring the external world, his approach tended to embody the separation he sought to overcome. This resulted in a host of dualisms asserted between center and periphery, fortress and village, technology and mysticism, city and country, all the way up to his discussion of the dialectics of nature in which nature is denuded to such an extent that it appears as merely the material and space ‘civilisation' (i.e. modern, urban consumer life) feeds upon (Marchand, 1978: 111). It was this rigid form of dialectics that was widely lampooned by post-structural geographers as possessing an inflexible ontology (one emphasising space rather than context) (esp. Jones, 1999), and which, alongside its association with the problematic history of Marxism caused widespread suspicion against dialectical approaches.

The relational turn in geography however, has brought with it a heightened receptibility to dialectical approaches - and a possible rapprochement of the nature and human relation. Against postmodern criticisms, Sheppard has demonstrated how dialectics can be read in a nonteleological manner. Building on Harvey's 'open-ended' model of dialectics, Sheppard has shown how processes, flows, fluxes, and relations do not exist "outside" of the "processes that create, sustain or undermine them” (Harvey, 1997: 49) and argues that it is precisely in thinking through complexity in ways in which many trajectories are possible that is the key benefit of dialectics (Sheppard, 2008: 2606). Harvey’s work, as is well known, has been instrumental in this growing engagement with dialectics throughout geography. In its epistemology, Harvey’s approach is 'open-ended' in that he sees contradictions "as containing the seeds of other contradictions" and which in turn require further exploration, thus precluding any "closure of the argument” (1982: 38, 446). Its ontology emphasises relationality, focusing on the most significant relationships at work in a given phenomena. As Castree summises, this ontology is very much indebted to Ollman's dialectical account of relations in which it is asserted that "each aspect of a social system cannot be comprehended outside its relation to all other aspects of that system" (1980, 26 cited in Castree, 1996). The result is a dialectic that is primarily systematic/epistemological and functions as an explanatory and diagnostic tool. Yet as it hinges 
on the adequacy of its account of relationality, Castree rightly identifies the problem of how this systematic dialectical approach can offer "a demonstration of all the social conditions, processes and interrelations necessary” (emphasis altered from original, 1996: 353). That is, Harvey's attempt to capture the most "significant aspects of capitalist reality," creates a tension at the heart of his dialectical procedure not just in identifying what the 'significant relations' are but also in reflecting these adequately. For Castree, this leads to an "immodest claim” that Harvey struggles to meet (1996: 358). Yet, for us, this is precisely where the modesty of the epistemological doubt and open-endedness of dialectics has considerable pay-off, for when we admit that reflection necessarily results in distortions that occur off any reflective surface, it becomes a question of how we account for these limitations (i.e. how we practice reflexivity) that is essential - and not coincidentally why Hegel names his dialectical philosophy as speculative (from the Latin 'speculum,' meaning 'mirror') (Butler, 2012: 19). It is not to retrieve a perfect image or to fill in the tabula rasa with unsullied content, but of "re-cognising" those common-sensical ways of approaching things, that is, in overcoming the mere appearance and immediacy of things that serves to separate the subject and object. In contradistinction, dialectics strives to see the subject and object as co-constitutive of the other, as an affinity, and it is for this reason that we argue for this reintegration of human and nature into dialectics, so that nature gets its due.

There have already been crucial antecedents to this task. Perhaps most famously was Reclus' "social geography" concerned with relations between human and nonhuman nature. Whilst his dialectical approach was built around moralising critique rather than drawing out social contradictions, ${ }^{1}$ it was how he dealt "with the whole" (Fleming, 1988: 114), as the reciprocal determination between nature and social forces, that set him apart from orthodox geographers. Arguably, contemporary theorists like Castree have furthered this way of thinking by engaging with Eco-Marxism's critique of the human (capitalist) relation to nature and by multiplying the actors and complexity of the policies involved in the 'society-environment nexus' (see 2002). Similarly, Braun has sought to overcome the dualistic conceptions of nature and society (2009: 26) by looking to what he and Castree call "social nature" - the ways in which nature is being remade through human action/thought (and the ecological and social consequences of this transformation) - that offers a new way of thinking "that attends to, and places us [humanity] within, the creative becoming of the earth” (Braun, 2008: 175). Such reimaginings on the 'society-environmental nexus' are in many ways compatible with our 
argument (see Braun \& Castree, 1998). Whereas Whatmore and others have been trenchant in their criticism of dialectics on this very point - as actually accepting a priori the binary logic of nature and society in ways that upend 'contradiction' as the “engine of history” (1999: 25) rather than overcome it - such attacks, in many ways, contain a plea for the same reconceptualization of human and nature that we pursue, whether expressed as 'society-environmental nexus' or 'human and nature affinity'. Whatmore's concern for “living in the world” (1999: 30) that emphasises networks and their connections belies a growing convergence in radical geographic thought with dialectical analysis that is also concerned with conceptualising the human and nature relation, not as a re-combination of dualities, but as an affinity. What animates each of these positions, then, is a question of how we come to, or approach, the world. As we shall demonstrate, Bookchin's dialectical naturalism - his concern with 'ecologising the dialectic' is what goes beyond the formulations advanced thus far in radical geography by ensuring that no relation is excluded a priori. We must acknowledge here that Bookchin is rarely viewed as a dialectician on par with the likes of Marcuse or Adorno. Nevertheless, he devoted much time to dialectical thinking and advanced it significantly in its relation to naturalism and ecology (see esp. Bookchin 1982, 1996a). While perhaps not as systematic as Adorno’s Negative Dialectics, nor as (yet) influential in comparison to Marcuse's effect on the New Left, the way Bookchin thinks through totality as including the nature and human affinity (something Adorno and Marcuse fail to adequately posit) is why we claim he should be considered as a dialectician par excellence and is one of the key lessons the dialectical tradition can learn from him.

We begin with an exploration of the dialectical approach of Herbert Marcuse, exposing the limitations that result from the application of this dialectical method to the question of the ecologism, arguing that the social totality necessarily includes the ecological foundation of human society.. ${ }^{2}$ In the second part, we point this dialectical framework to the accelerating ecological crises of today (climatic, biospheric and oceanic) that form the objective contradictions - the 'problem' - unique to our age (Dunayevskaya, 2012: 36). In this context, we turn to Murray Bookchin's ‘dialectical naturalism' as containing key insights into what a dialectical method, if situated and focused on ecologism, promises for a radical politics of the present. We outline how a dialectical approach focused on negativity, open-endedness and which is directly located within, and takes as foundational, the ecological conditions of human society can offer an enhanced understanding of the social totality and thereby locate the social resources 
necessary to sublate the contradictions of alienation, domination and destruction endemic to contemporary social life and its tragic split between nature and human.

\section{Marcuse and Dialectics}

Marcuse's revised introduction to Reason and Revolution offers the most lucid accounts of the dialectical method that permeates his entire corpus of work. Here, Marcuse defines dialectics as "the power of negative thinking," a specific refinement of Hegel's "negation of that which is immediately before us" (1982: 444). As Marcuse explains, dialectics is the philosophical exposition of the contradictions between facts and concepts, the exposition of the void between reality and its conceptualisation that fail to see the contradictions within 'the real.' This notion of negative thinking evinces a concern with uncovering both the potentialities immanent to 'the real' but which are denied and the limitations of 'the real' that go unchallenged: "the real field of knowledge is not the given facts about things as they are, but the critical evaluation of them as a prelude to passing beyond their given form” (Marcuse, 1973: 145). Other approaches to the social sciences however, with positivism being the most extreme example, accept and affirm the given facticity of reality in their methodological principles. That is, they remain focused on what 'is' - thereby falling to the illusion of appearance - and subsequently "purge" reality of its contradictions leading to a failure to see the "given state of affairs on its own grounds" (Marcuse, 1982: 444-445). Any subsequent claims made by such approaches as to the comprehension of reality is rendered false and deeply ideological.

In contrast, for Marcuse, dialectics illuminates the actual contradictions within 'the real' by offering an immanent critique of "the established system of life" on its own grounds, exposing its "promises and potentialities". And it is this critical function that Marcuse isolates as "negative thinking" - the exposition of the "promises and potentialities" within the given reality that are denied or repressed by the status quo. Negative thinking is the "driving power" of dialectics that can expose the "internal adequacy" of accepted facts of "the real"' (Marcuse, 1982: 444-445). While Marcuse denies this is ontological, his conception of dialectics is

premised on an ontological claim because the power of dialectical thought to judge the inadequacy of given facts is made possible only on the assumption (and foundational claim) that subject and object are joined: facts embody the knower (which, clearly, has epistemological consequences too). The question, however, is how adequate is Marcuse's exposition of the 
'promises and potentialities' of that which is 'immediately before us'? Given that all forms of thought are conditioned by social relations surrounding them, how can he assure us that his own dialectical analysis is not entrapped by 'the real' or does not fall to conformity with the status quo?

Marcuse appeals to the continued presence of dynamism in the status-quo even though, as he claims, it has streamlined domination, appears to "operate endlessly," and has delayed "indefinitely" the "emergence of new modes of existence with new forms of reason and freedom." (Marcuse, 1982: 445) This is because set against 'the real' is Hegel's ontological concept of freedom: to be the subject of one's existence and realisation. For Hegel, as for Marcuse, "the energy of nature and history" is the process of transformation toward this 'consciousness of freedom'. But what perverts this transformation is precisely what dialectics exposes in social life; that is, how humanity and nature exist in "conditions of alienation": how they exist 'other than they are'. The beginning of dialectical thought, for Marcuse, is this experience of the world as "unfree", and basing itself in this contradiction provides dialectical thought its logical ground to grasp the (contradictory) structure of reality and to "drive beyond" its mere "factuality." Social contradictions are, for Marcuse, experiential, phenomenological, something felt. The subject's experiences of unfreedom is what pushes against historical structures as the "continuous negation of that which threatens to deny (aufheben) freedom." Even though freedom remains negative in this sense, history is the process of the (possible) "comprehending and mastering" of alienation towards the goal of a 'state of the world' in which "the conditions and relations of [this] world 'possess no essential objectivity independent of the individual'” (Marcuse, 1982: 446-447)'

Yet, despite this dynamic potential, Marcuse admits that the dialectical language of contradiction is itself part of the "game" of the dominant discourse of the status quo because, as he writes in parenthesis, 'there are no others'. This seems, at best, a passive admission that dialectical thought remains bound to existing structures of domination and, at worst, that it can do nothing to break from them. Marcuse as such, relies on a thoroughly immanent dialectics to retain some emancipatory possibility: dialectics exposes the limits of 'the real', its contradictions, its failures, its potentialities. It pushes against, and may open up space for liberation. Yet, at the same time, this represents a clear boundary condition for dialectics that 
remains transfixed in what Marcuse called the "mutilated whole” (Marcuse, 1982: 448-449). That is, the ambit of dialectical speculation is curtailed within given social conditions. Nevertheless, insofar as his methodology is concerned, Marcuse looks to how the concepts/facts that are "codified in the language of the game" can themselves be redefined through their determinate negation of the unfreedom of 'the real'. Here, determinate negation:

“... refers the established state of affairs to the basic factors and forces which make for its destructiveness, as well as for the possible alternatives beyond the status quo. In human reality, they are historical factors and forces, and the determinate negation is ultimately a political negation” (Marcuse, 1982: 449).

So, whereas the power of negative thinking can expose the "promises and potentialities" in "the real', determinate negation of 'the real' exposes the historical "factors and forces" which make possible the political destruction of, and opens alternatives to, the status quo. These are two-sides of the same movement: the former identifies the potentialities in the present; the latter identifies the conditions of possibility that can be acted upon, thus redefining the very concepts/facts saturated by 'the real'. Without either step, Marcuse’s dialectic would remain incomplete - a test that Marcuse's own analysis would ultimately fail, as we shall see.

The dialectical architecture of Marcuse's approach is both compelling and problematic. Whilst it centres on the conceptual/factual inadequacies of the status quo, and identifies historical factors and forces for the potential resolution of present social contradictions, this process is utterly dependent on the identification and rational projections of the dialectician. The problem is more than the fact that the dialectician acts to confine or widen the field of possibility based on what 'factors and forces' they include in analysis. More disconcerting is that the identification of these conditions of possibility relies on some prior (and by necessity perpetual) ability for critical thought to undertake this function of 'negative thinking' throughout history. That is, there must be some pre-condition for critical thought to emerge and be resistant to the dulling of negative thinking under the weight of social domination that serves to continually reinforce the separation of the subject and object, human and nature.

Marcuse's narrow vision of political possibility - a thesis that would become particularly pronounced in One Dimensional Man - stems precisely from his assessment of the desirious 
effects of technology on the re-emergence of rational thought, and thereby the possibilities for human emancipation. In similar refrain to Horkheimer and Adorno's Dialectic of Enlightenment thesis, Marcuse came to see little social resources left in the West for positive transcendence of the domination of instrumental rationality. ${ }^{3}$ This political assessment was already prefigured however, in the outline of his dialectical method in which he asserted that 'technological reality' had conjoined the subject and object "so closely that the notion of object necessarily includes the subject...” The originary ground of dialectics, the view that subject and object are joined (and thereby that facts embody the knower), is overcome: in late capitalism, object dominates subject. The ambit for dialectical thought to help lead to a "more genuine reality" is ultimately arrested or closed by ‘technological reality'. As Marcuse writes:

"Those who enforce and direct the conquest [of matter, sic, nature] have used it to create a world in which the increasing comforts of life and the ubiquitous power of the productive apparatus keep man enslaved to the prevailing state of affairs. Those social groups which dialectical theory identified as the forces of negation are either defeated or reconciled with the established system. Before the power of the given facts, the power of negative thinking stands condemned (Marcuse, 1982: 451).”

This was not just a simple re-assessment of the relative strength of the revolutionary subject, but a fundamental reversal of the potential for dialectical thought to emerge and sublate the subject/object as an affinity. Horkheimer had insisted on this materialist "logic" (1946: 168), and Adorno had gone so far as to locate the deficiency of bourgeois philosophy in its failure to understand the subject/object relation (see Held, 1980: 201). Yet with Marcuse's move to a conception of modernity in which the object now includes the subject, he could no longer claim any ground for the possible re-emergence of negation that was silenced by the sheer power of accepted concepts/facts of the 'technical apparatus'. Against this historical rupture, how then can the 'power of negative thinking' be rekindled to reveal to Reason that it is itself "still unreasonable, blind, the victim of unmastered forces”? (Marcuse, 1982: 450).

Reason has been colonised by interests of instrumentalistion in late bourgeois society, driven to serve only the profit motive and the narrow interests of domination: severing not only 'human from human' but 'human from nature'. Bourgeois science reflects this overriding purpose of use value. We one need look no further than 'climate scepticism' as the last in a long 
line of degenerations, as thought itself finally succumbs to not only reflect, but become, dominant ideology. As Marcuse laments, "the subject that has conquered nature suffers under the dead weight of his conquest” (1982: 451). Against the dominance of 'technological reality', Marcuse offers a week entreatment that thought "continues to protest in the name of truth" (1982: 451). And it is in this context that Marcuse gives us the first indication of the potential of nature in revivifying dialectical thought toward an emancipatory horizon. For Marcuse cites "the waste of resources" as a factor in the perpetuation of the status quo and as one of the "unresolved contradictions" - part of the logic of things - that are "capable of piercing the ideology and of comprehending reality whole” (emphasis added, 1982: 451). ${ }^{4}$ One can read into Marcuse here the suggestion that the environmental waste of bourgeois society leads to its determinate negation. That is, the most basic historical 'factors and force' of capitalist waste redefines the very language of progress, development, and technology of modern society and makes for the conditions of the destruction of the status quo. The abundance of waste, that is so obvious, so self-evident, and yet banal, compels a negative comprehension of reality:. indeed, such “nonpolitical language” may be the most "authentic expression” of absolute negation (1982: 451). This gestures to the importance of ecological basis of the 'whole' and while Marcuse ultimately neglected to systematically examine this potentiality, it is telling that he would turn to this just before his death (see Marcuse, 1992).

\section{- Beyond Marcuse: Towards an understanding of Dialectics and Ecology}

As we have seen, Marcuse’s assessments of 'technological reality' tends to eclipse his optimism, despite the repeated claims made throughout his work that the liberation of society remained a 'vital need' - claims that become, in the absence of social resources necessary to sustain them, merely rhetorical (Marcuse, 1965: 105). For him, rationality itself had been reduced to "a set of truth values which hold good for the functioning of the apparatus - and for that alone” (Marcuse, 1998: 41, 49). The overall tone of Marcuse’s work is “imbued” with the centrality of one-dimensional society that has rendered liberation impossible (Anderson \& Rockwell, 2012: xliii). Yet, the very criticisms Marcuse levelled against existentialism as falling to the "the very ideology which it attacks", can be said of his own hypostatization of what is a specific historical condition into something ontological and metaphysical (1948: 311). That is,

Marcuse's sees the possibility for negative thought as being 'trapped' by the ideology it could 
expose. Any radicalism that dialectics could (re)claim belonged to a future lost to possibility. But this mystifies what dialectics is primed to uncover by projecting the dominant features of modernity and thus conflating (bourgeois) technological society as reality itself. Marcuse's projections lacked any systematic engagement with broader societal processes, those going on outside the West, and dirempted from the wider ecological context,, resulting in a false rendering of the social totality. This failure is attributable to Marcuse's theoretical choices: he did not engage with social agency or the natural conditions (the 'objective' relations) but rather to economic, productivist and technical categories (a nominalist and productivist 'lens' that is itself the product of bourgeois interests and technological society) that he abstracted from the 'whole'. Without mediating these categories against a far more expansive notion of 'the real' (inclusive of nature), Marcuse became trapped by his own projection. As he claimed, whilst the "present stage redefines the possibilities of man and nature in accordance with the new means available for their realization” this had achieved very little under advanced industrial society that had merely replaced personal dependence "with dependence on the 'objective order of things' “ (on economic laws, the market etc.)” (1968: 65, 144). An alternate dialectical approach however, could highlight the many dimensions of the social totality - the 'whole' - that had been left out of Marcuse’s analysis, including nature.

Yet towards the end of his life, Marcuse did speak to ecologism, on the basis of which some have suggested that a society without violence, destruction, and pollution was part of Marcuse’s vision of liberation (Kellner, 2005: 33). Marcuse did proffer a revealing account of the radical potentialities within the ecologist movement - something that he saw as a revolt of "life instincts" against "socialized destruction" and as the attempt to "subordinate destructive energy to erotic energy” (Marcuse, 1992: 37, 36). However, this radicalism, once again, falls to ambivalence and pessimism based upon his overriding conception of technological society. In one of his last talks, Marcuse located the sources for 'institutionalized destructiveness' including "the general poisoning and polluting of our life environment" - in the Freudian category, Thanatos. For him, any radical change, including the overcoming of this destructiveness, must be reflected in individual consciousness and unconsciousness, rather than just institutionally. And yet the 'reality' principle socialised in institutions that guides individual drives, the division of labour, and the power structure, reinforces affirmations of, and conformity 
to, the established system of needs (Marcuse, 1992: 30, 32). Any increase in Thanatos thereby corresponds to a weakening of Eros in a tragic zero-sum game: the "preponderance" of Thanatos will, ultimately, overcome erotic energy in favour of the destructive. This suppresses the emancipatory potential of ecologism - in ways similar to how Marcuse saw the closing of negative thinking under technological rationality, discussed above - by holding the intersubjective relations as dominated by the symbolic order of institutionalized destructiveness (see Kovel, 1992: 42).

So despite this ecological turn in Marcuse's considerations, the same closure of the dialectic, the same suspension of historical process and emancipatory potential takes place. As he writes:

"Under the conditions of advanced industrial society, satisfaction is always tied to destruction. The domination of nature is tied to the violation of nature. The search for new sources of energy is tied to the poisoning of the life environment...” (1992: 32-33)

In this dystopia, Marcuse sees that the "repulsion from historically possible change" as actually residing in the "individuals themselves," that is, in their basic instinctual structure (1992: 35-36). So despite the ability of ecologism to subordinate 'destructive energy to erotic energy,' this pertains to only few individuals rather than across consciousness, unconsciousness, and social institutions necessary for radical change. Indeed, the individualised form of the contemporary ecologist movement is seen by Marcuse to militate against the types of "organisation" and "selfdiscipline” necessary for such radical change to take root (1992: 38). For Marcuse, the question is whether ecologism can offer a direct, sustained and ongoing challenge to the existent "mode of production and model of consumption" - and he is less than hopeful for the realisation of an 'authentic ecology', militancy and socialist politics (2005: 175-176). Ecologism's weakness is more than just the potential for its co-option by dominant interests. For within capitalism nature is merely an "object of exploitation" and having become part of capitalism, "serves to strengthen human servitude." Nature comes to be viewed, under the predominating liberal tendencies of the ecology movement, not as a potentially complementary agent in human history but a perpetually alienated, ontologically given bundle of 'resources' to be instrumentally 'managed' (see 
Löwenthal, 1987: 242-243). For Marcuse, this is the "insurmountable internal limitation of any capitalist ecology” (2005: 176). Nature has itself been overridden by the expansionist tendencies of capitalist production, its 'space' colonised by the same interests of domination, servitude and exploitation of the technical apparatus. Any potential for dialectical rupture is closed once again.

Marcuse's failures are then properly identified in the absence of an interrogation of nature as fundamental to the 'factors and forces' of historical change, in particular, the environmental limits of the 'technological reality'. The interlocking ecological crises has made apparent the sharp contradictions lying at the heart of bourgeois society and reveal that it cannot last for perhaps more than one century (if recent IPCC projections are correct). This exposes the "absolute contradiction between social wealth and its destructive use" (Marcuse, 2005: 174) that Marcuse, in his time, did not foresee. The immediacy of environmental crises have shifted beyond the projections of Marcuse's dialectical analysis, for in this context genuinely negative thinking must reflect the alienation of 'human from human' and humanity from nature, that lies at the very core of bourgeois society, whether as rational choice, individual self-maximisation or Homo Economicus. For all of these ideological expressions of the capitalist 'development' project presuppose not only the radical separation of human subjects from each other but from the natural world around them. Dialectical thought must acknowledge this relation as part of the totality, rather than reify one aspect of domination and remaining at this level of abstraction. For humanity's alienation from nature appears necessary to the status quo, the technical apparatus, and interest of domination only if one buys into the fallacy of the ontological separation of human/nature. Contrary to Marcuse's interpretation, ecological crises expose the alienation at "the core of things" and by confronting 'the real' with these limitations that it denies, determinate negation can become the "positive act" that Marcuse outlined that it could be: namely, falsifying reality and opening the "real possibilities" denied in the present (1982: 447448). But in so doing requires us to see the human and nature as affinity, that is, conceiving the basis of all social life within the complexity of the ecological system and determinate negation as the exposition of the underlying social contradictions based in, having effect on, human and nature.

\section{'Nature' as Ideology: Critical Reflections on the Ecology Movement}


Regardless of the othewise radical benefits of his dialectical approach, Marcuse did not solve the problem of the reification of nature.. In this section, we explore the political relation between dialectical philosophy and the ecology movement as a steps towards this reconciliation, suggesting the rupture between humanity and nature can be overcome by moving to dialectial naturalism. For when we consider the relation between dialectical philosophy and the ecology movement, we are inevitably forced up against one of the most entrenched prejudices of our time: what Adorno referred to as “action for action's sake” (1998: 290). As Adorno well understood, the compulsion to jump into the immediacy of the barricades and police clashes, leaving the coherence and purpose of social action to little more than an afterthought, betrays the absence of negative thinking and a distinct tendency toward unconscious manipulation - a danger keenly recognised, and profitably exploited, by the apparatus of the culture industry. This is not to absolve Adorno's own disdain for the 1960s activism that can, arguably, also be seen as a response of such unconscious manipulation.

Rather than 'jump in' to the usual laundry list of petitions, catch-phrases and the bureaucratic 'work' of green parties, the ecology movement must strive to make a lasting and meaningful impact upon the social maladies that are producing the earth's ecological crisis. A real concern is to ensure that the movement itself does not become complicit in the reproduction of the perverted logic of the status quo - and which justifies the urgent need for a dialectical naturalism to ground negative thinking in the present. By redirecting the rational desire for a social totality not premised on the domination of nature and humanity into reformist 'solutions' designed to preserve the deeply irrational and anti-ecological organisation of contemporary society, the ecology movement risks being co-opted into precisely the same forms of social irrationality which have produced the ecological crisis in the first instance. A commonplace strategy through which this ideology solicits itself is through the demand for "immediate action": the repressive and relentless demand 'to do' rather than 'to think'. Such reactions preclude dialectical reflection, "the hard labour of the negative," that alone promises to enable the ecology movement to break out of the mould of reified consciousness. An equal danger rests in the contemporary relationship between mass culture and political movements. The rise of identity politics' could be understood as the surface phenomenon of a much deeper social pathology: 
namely the reduction of formerly fecund political movements to a monadic subjectivism and consumption logic which occludes any meaningful reflection on the relation between ends and means. Moreover, the grossly inadequate appeals by the ecology movement to the state or 'corporate social responsibility' usurp a more meaningful, conscious and radical approach toward the ecological crisis that aims to get at the social roots of the problem, rather than simply its surface appearances.

Murray Bookchin has offered one of the most sustained critiques of such tendencies in the ecology movement, locating them in the dialectical contradictions presented by the dominion that bourgeois ideology has perpetually exerted. Perhaps the most obvious contradiction is, as revealed by Marcuse and the younger Bookchin, the obvious disparity between social wealth i.e., the possibilities of a 'post-scarcity' society - and the actual social use of this wealth under late capitalism for repressive ends (Bookchin, 1986: 53ff). Yet there is a far more subterranean contradiction in bourgeois society. It originates in the often subconscious yearning for a rational society, a society based not in the reduction of 'nature' to a mere object to be dominated, nor on the tyranny of needless toil and wretchedness, but the vague visions of a society that reflects and develops the diverse potentialities of human creativity and intelligence - rather than repressing them under the logic of exchange and irrational authority-structures. This desire is something produced not out of the 'autonomy' of an 'ego', but rather by the social reality of alienation, as the younger Marx keenly observed (see Marx, 1959). Yet this desire is denied by the prevailing social system of late capitalism. For its fulfillment would require a revolution in the very fabric of society that would put an end to the prevailing political and economic power structure which produces alienation and, through its ideology, mystifies this process as a 'natural' one.

The denial of this yearning leads to its accompanying mystification of what are actually social pathologies into personal ones, a process by no means unique to bourgeois society. To cite Bookchin, in the context of his critical essay on postmodernism:

"Not surprisingly, there is a certain symmetry between the emergence of postmodernism as a widely accepted ideology and the emergence of the social circumstances that have made it so widely acceptable. Various societies do foster ideologies that render their 
pathologies tolerable by mystifying the problems they raise... Today's market society is no exception to this rule. The very tendency of mature capitalism to fragment traditional social and cultural relations by means of commodification yields reactionary cultural sequelae of its own: specifically, a consolidating ideology that holds the mind captive to the social order in the very name of fragmentation and its alleged virtues” (1995a: 175).

The concept of 'nature', as it manifests in part of the ecology movement, is a remarkable example of how mystification can easily distort the more rational and revolutionary potentialities of an ecological awareness. This mystification is, however, part of an ideological history. Many philosophers of the bourgeois Enlightenment, in championing instrumental reason through the purely technocratic progress of science, defined the very notion of progress against a recalcitrant 'nature.' This was even evident in Hegel and Marx (and to a degree, Marcuse) whose dialectical analysis did not extend to a challenging of the bourgeois notion of a universal antagonism between humanity and nature. This act of defining humanity against the natural world was a resounding archetype for the process of psychological repression characteristic of bourgeois social life that envisioned 'reason' and 'nature' as locked in a fatalistic and universal struggle.

On the other hand, the glorification of 'nature' vis-a-vis human reason tends to lead to a pervasive irrationalism that, arguably, merely releases the various sicknesses of the collective unconscious into a mirror image of 'nature', which is little more than the reflection of its own violent undercurrents. Historical examples of this include German fascism, founded on its ideology of blood and soil, its more recent configurations in eco-fascism, and the deceptively reactionary notions of anarcho-primitivism and deep ecology. ${ }^{5}$ The glorification of nature and the accompanying deprecation of human rationality, terminates in the one-sided and often destructive attitude toward all that exists, with a view toward returning to an illusory prelapsarian utopia, or in the championing of a Malthusian 'Year Zero'. Either polarity lacks the understanding of dialectical naturalism that sees humanity and nature as intimately bound, as equiprimordial.

In invoking the holy symbology of natural authenticity, it is likely that this type of ecological movement, ironically, renders itself all the more captive to reification. As Adorno 
once said "such naiveté reproduces itself incessantly and disastrously" (1998: 12). The concept of 'nature' is always a potential victim for reification, and rarely does it escape the gravitational pull of dominant ideology (as we have seen in the dogmas of Malthusianism, anti-humanism and primitivism). What is missing is a dialectical awareness of how the movement of history has continually produced the social potentialities of its own negation, only to have these potentialities subsumed under the swampy mists of reaction and unreason. In Bookchin's words:

"History, insofar as we conceive it as the unfolding of humanity's rational component its developing potentiality for freedom, self-consciousness, and cooperation - is a complex account of the cultivation of human sensibilities, institutions, intellectuality, and knowledge, or what was once called "the education of humanity." To deal with history as a steady "Fall" from an animalistic "authenticity," as Zerzan, Bradford, and their compatriots do in varying degrees in a fashion very similar to Martin Heidegger, is to ignore the expanding ideals of freedom, individuality, and self-consciousness that have marked epochs of human development - not to speak of the widening scope of revolutionary struggles to achieve those ends” (1995b: 48).

To widen the scope for struggles against the social causes of the ecological crisis, we are obligated to cast off the banal conceptual discourse through which bourgeois society rationalises ecological crisis - as redolent in phrases such as 'market environmentalism' and 'green consumerism'. A basic prerequisite for the reinvigoration of a revolutionary, coherent, and rational ecology movement is for it to avoid the simplistic reduction of its social consciousness to a false dichotomy between the evils of 'industrial civilisation' and a primordial 'nature'. It is exactly this one-sided attitude toward social reality that can be overcome through a dialectical naturalism, making it possible to confront the objective reality of the ecological crisis beyond the limitations of the socially-inculcated one-dimensional consciousness that Marcuse so lamented.

\section{The Necessity of a Dialectical Naturalism}

The attempt to understand the objective reality of the ecological crisis requires an awareness of the dialectical contradictions of history - especially in the relation between human 
beings and their natural environs. Fortunately, Bookchin's notion of a 'dialectical naturalism' offers a unique means for us to comprehend the rational potentialities in 'the real' which bourgeois civilisation has cast aside, denied, or left unrealised. However vaguely Bookchin may have formulated his concept of dialectical naturalism, it nonetheless evokes the glimmer of the hidden possibilities of a more rational relation between human social organisation and the natural world. It is, as Marcuse maintained somewhat inconsistently, only through the nuances of dialectical thought that 'naturalism' may be emancipated from its degraded status as a mere object of ideology.

Traditionally, the great merit of dialectical thought is that it has always sought to move beyond the ideological limitations of the here and now, the prejudices that limit social relations from unfolding to their inherent potentialities. To borrow earlier from Marcuse, the power of dialectical analysis lies in exposing how 'the real' opposes and denies the potentialities inherent in itself. This involves both a critique of ideology (already indicated above) and expanding our consciousness of the potentialities of history and of civilisational development more generally. This is precisely the two-fold task that Bookchin's notion of 'dialectical naturalism' undertakes. One of the most pressing tasks, as Bookchin conceives it, is to expand our awareness of the ethical potentialities bound up within the movement of history. This is directly related to a critique of the bourgeois conception of nature as mere utility that remains pervasive both culturally and psychologically. ${ }^{6}$ A dialectical naturalism would, in contradistinction, allow us to glimpse the intro-reflected and symbiotic relation between human and natural history, without reducing either into an instrumental and domineering 'single science':

“...Subjectivity and specifically human consciousness... cannot be ignored in formulating an evolutionary theory. We may reasonably claim that human will and freedom, at least as self-consciousness and self-reflection, have their own natural history in potentialities of the natural world - in contrast to the view that they are sui generis, the product of a rupture with the whole of development so unprecedented and unique that it contradicts the gradedness of all phenomena from the antecedent potentialities that lie behind and within every processual 'product.' Such claims are intended to underwrite our efforts to 
deal with the natural world as we choose - indeed, as Marx put it in the Grundrisse, to regard nature merely as "an object for mankind, purely a matter of utility" (1999: 45).

Given that dialectical analysis addresses the whole, it must necessarily accommodate the discoveries of ecological science in its account of human and natural history. This, in turn, culminates in the infusion of dialectical analysis with ecological ethics. As argued by Bookchin:

"The compelling dictum, “respect for nature," has concrete implications. To assume that our knowledge of this complex, richly textured, and perpetually changing natural kaleidoscope of life-forms lends itself to a degree of "mastery" that allows us free rein in manipulating the biosphere is sheer foolishness” (1982: 24-25 cited in Bookchin, 1990).

Indeed, what dialectical thought has lacked in previous epochs of history is an awareness of how reason itself is an implicit potentiality of the natural world. The false dichotomy between reason and nature, as if we must choose between the mythic primitivism of 'deep ecology' and the manipulative instrumentalism of liberal environmentalism, reflects the institutionalised prejudices and practices of social relations deformed under bourgeois society, just as it reflects the inability to move beyond the false oppositions which have emerged not from an objective engagement with nature but through the distortion of nature by way of the conceptual identity imposed upon it. In relating nature and reason as presupposed opposites, we deny the extent to which they presuppose one another:

'It is grossly misleading to invoke 'biocentrism,' 'natural law,' and antihumanism for ends that deny the most distinctive of human natural attributes: the ability to reason, to foresee, to will, and to act insightfully to enhance nature's own development. In a sense, it deprecates nature to separate these subjective attributes from it, as though they did not emerge out of evolutionary development and were not implicitly part of animal development” (Bookchin, 1995c).

Dialectical naturalism does not therefore advocate a hubristic "stewardship" of nature at the hands of humanity (see Bookchin, 1990). Rather, through a successively-graded series of determinate negations, humanity - through the development of its own 'second nature' - 
gradually becomes conscious of its own potentialities for reason and freedom. Through this drawn out historical process of self-awareness and capacity for self-determination, humanity may gain the ability to choose paths which would lead not only to its own self-harmonisation and rationality but, as a logical corollary to this, to a form of ecological society reflective of harmony between humanity and nature. The historical process of human 'second nature', therefore, has never in truth been something isolated from 'first nature' but is actually a process of reciprocal determination. Within this dialectic remains the unactualised potentiality for a more rational, and therefore ecological, society. As Bookchin claims:

"It is eminently natural for humanity to create a "second nature" from its evolution in "first nature." By second nature, I mean the development of uniquely human culture, with a wide variety of institutionalized human communities, effective human technics, richly symbolic languages, and carefully managed sources of nutriment. Dualism, in all its forms, has opposed these two natures to each other, as antagonists. Monism, in turn, often dissolves one into the other - be it liberalism, fascism, or more recently, the biocentrism that so closely approximates misanthropic antihumanism. These monist ideologies differ primarily in whether they want to dissolve first nature into second or second nature into first” (1987: 21).

All forms of monism and dualism are one-sided by their reduction of history into this simplistic process of dissolution. Indeed, they are a product of the dominant ideology that they both embody and reflect:

"What these dualisms and monisms have in common is an acceptance of domination. Classically, the counterpart of the "domination of nature by man" has been the "domination of man by nature." Just as Marxism and liberalism see the former as a desideratum that emerges out of the latter, so enthusiasts of "natural law" accept the latter as a fact and condemn efforts to achieve the former. These views are deeply flawed - not only because they are conceptually one-sided or simply wrong, but because of the way they are philosophically structured and worked out. The real question, I submit, is not whether second nature parallels, opposes, or blandly "participates" in an "egalitarian" 
first nature; rather, it is how second nature is derived from first nature... The ecological crisis we face today is very much a crisis in the emergence of society out of biology, in the problems (the rise of hierarchy, domination, patriarchy, classes, and the state) that unfolded with this development, and in the liberatory pathways that provide an alternative to this warped history” (1987: 21-22).

Bookchin's magnum opus, The Ecology of Freedom, is an attempt to explore such alternative, liberatory pathways through a dialectical analysis of the relationship between natural and human history. Whilst an account of its nuances and leitmotifs cannot possibly be given here, its dialectical historicism aims to actualise the potentialities of history rather than merely producing the 'facts' as in the positivist tradition and its 'truths' that are vulnerable to ideological capture. Much like Hegel's Phenomenology of Spirit and Benjamin's The Arcades Project, its overall concern is to present an analysis of the movement of history (in Bookchin's case, of the hierarchical relation between human domination and the domination of nature leading up to the ecological crisis) without becoming confined within the ideological categories through which this movement has become understood in 'official history' (Bookchin, 1982: 65). It presents an introjection of naturalistic and dialectical philosophy: an attempt to document and give voice to the possibilities of an interrelated first and second nature. At the same time, it also connects the failure of revolutionary movements of the past to the degraded actuality of the present, especially the concrete social factors underlying the ecological crisis (hierarchy, class, patriarchy, and the emergence of capitalism). Here, Bookchin's more dynamic treatment of class (inclusive of women, youth, disenfranchised) is quite different to Marcuse's, its wider basis bringing with it a wider conceptualization of totality and relations therein. This wider ontological commitment allows Bookchin, to see ecological problems as the product of the domination of people by people, as part of the same pathology of hierarchy. ${ }^{7}$ Stated positively, it is in these ways, that Bookchin's approach gestures to the radical possibility contained within a dialectic that grasps human and nature as an affinity.

Despite this potential, the ecology movement, as a whole, is yet to take seriously the potentials of dialectical thinking. This is symptomatic of the contemporary Left, which has atrophied in the face of the various maladies of the neoliberal era. Dialectical naturalism can 
contribute to a revolutionary renewal of the ecology movement by exposing how the real opposes and denies the potentialities inherent in itself. That is, dialectical naturalism allows for a reengagement with future reconstruction - the 'could-be' of an emancipated and egalitarian society free from domination and exploitation - by reconciling the fundamental relation between humankind and nature. In this way, it reinvokes the subject/object relation that was reversed in Marcuse’s conception of ‘technological reality’ (i.e. object dominates subject). Nor does it make the same false assumption that society and humanity are separated from natural evolution. Rather, it uncovers the ideology that identifies "human progress with the idea of dominating nature." It is evident that capitalism (both corporate and state) maintain the idea of controlling nature as a deeply systemic factor in social life (see Marcuse 1990) - but what is usually overlooked is that the collapse to one-dimensionality in Marcuse's thought is but an example of dialectical thought succumbing to this systemic bias also.

An example of what possibilities are opened by dialectical naturalism can be seen in Bookchin's account of technology - an example that contrasts sharply with Marcuse's own reading in which technology seemed bound to the reproduction of the "totalitarian-technological stage" (Marcuse, 1965: 103). ${ }^{8}$ Dialectical naturalism charts a different course grounded in an understanding of the rational potentialities of technology, particularly in the interests of ecological restoration (a task which is becoming increasingly unavoidable with the advanced state of global warming and is redolent in policies/practices of climate 'adaptation and mitigation'). As Bookchin states, we falsely identify technology and population as part of the problem, seeking to treat the symptoms instead of the pathology (2009: 285). The question, rather, for Bookchin is not of either denouncing or applauding growth in "social productivity" as for Marcuse (1965: 104) - it is about the movement toward the conditions of genuine human association located in, and in unity with, our natural environment. Far removed from an anthropocentric vision of stewardship, Bookchin looks to a form of "ethical humanly scaled community that establishes a creative interaction with its natural environment” (1996b: xvii) Essential to this vision is a decentralized, non-hierarchical formulation of society as a foundation to dialectical naturalism. Essential to this is "theme of complementarity" or "integration" in which the relation between humanity and nature is restored at a "fuller level of mutualistic harmony" (1987: 38, 32, 21). It should be noted how this recalls Reclus’ emphasis on “small, loving and intelligent associations” as paramount to 
freeing ourselves from social domination toward an emancipatory "fraternal society" (Reclus, 1911: 3:183) Here, reflection on the rational potentialities or social intelligence affirms the notion that people are self-consciously transformative, and thus possessing a capacity however latent, for opening a space in which theory and practice may converge regardless of the seemingly monolithic power of domination. ${ }^{9}$

Whereas technology was regarded by Marcuse as repressive, for Bookchin, technology is part of nature, part of the evolutionary process. It is social hierarchy that sets nature apart as something to be dominated and which renders technology captive to particular ends that seek to objectify it. As stated by Bookchin, it is the "harshly objective factors" driven by the market the 'laws' of supply and demand', of “dehumanising competition” - that are "impervious” to "ethical persuasion" in the pursuit of growth and profit that "preclude a meaningful ecological orientation”. This does not evince a superficial engagement with capitalism, on the contrary, its emphaises on relations rather than material features alone, offers a wider critique of the effects of capitalism on society, intersubjectivity and nature. In effect, Bookchin is pushing towards a different geography and dialectics anathema to any hierarchical imposition. ${ }^{10}$ Bookchin's social ecologism is able to identify that the key problem is social, for under these pathological conditions, technology services only “destructive capitalistic ends.” In contradistinction, dialectical naturalism advances the notion of complementarity in which human beings play a "supportive role" in maintaing the biosphere - a "creative" function that includes the deployment of rational-technological capacities with, and for, nature. Such a view takes as fundamental the relation between humanity and nature, and the grave responsibility that "the future of life on this planet pivots on the future of society” (Marcuse, 2009: 292, 293, 294-295). This synthesis results in a creative self-conscious in which humankind is involved with nature "with the best practices" - including technology, or more specially, ecotechnologies that would offer a profoundly new symbiotic relation inclusive of technology and the ecocommunities in which they are located. ${ }^{11}$ This determinate negation of restrictions on nature, technology and humanity, offers a compelling account of what possibilities are opened by a dialectical naturalism. This fits well with Gordon's assessment of the relation between anarchism and technology for it emphasises the "inherence" of social relations in technological design and deployment (see 2009) but to which we would add that it allows not only for the judgement of technologies according to their 
promotion of hierarchical or nonhierarchical social practices but also their supportive or nonsupportive ecological orientation. The point of dialectical naturalism is to help understand, identify and overcome what blocks the potential of a "liberatory technology" (Leff, 1998: 69), to arrest those social forces that impede the internalization of ecological concerns, and to adjust technology to ecological conditions of conviviality and sustainable production. This potentiality would require nothing less than a sweeping and revolutionary change of social relations - a society moving toward the abolition of all forms of domination, hierarchy, and class, and therefore a society that moved to do away with all of the antagonisms that turn technology blindly against human beings and against nature.

\section{Conclusion}

In this article we have tried to show the limitations that can result in dialectical analysis in the absence of ecological understanding of the totality. Marcuse's limited application of dialectical analysis contributed to a oversight of the necessary implication between dialectics and nature, the comprehension of the social totality, and thus severely curtailed emancipatory politics. This one-sided analysis contributed towards skepticism, even a fatalist resignation in parts of his work: for in a world of advanced industry and technical progress, Marcuse sacrificed dialectics to the perceived dominance of 'the real'. In juxtaposition, dialectical naturalism - as advanced by Bookchin - seeks to expose the transitory and partial nature of 'the real' and to expand our awareness of the potentialities of the age. Whilst we have only outlined the first steps in how dialectical naturalism begins to break through the reified and distorted concept of 'nature' that is separated from humanity under the dominant ideology, it does so, though Bookchin's understanding of "second nature" and "first nature" that does not dissolve either into the other, nor establish them as existing within a universal, and ultimately false, antagonism. Instead, nature and reason (in the most universal sense) are seen to co-exist within a historical process of reciprocal determination, as an affinity. Dialectical naturalism restores to dialectic the awareness that totality is always fleeting and non-identical to its appearance, its 'official' public relations image that glosses over the 'mutilated whole'. Marcuse' despair and ambivalence was directly attributable to the absence of nature in his dialectical approach. Yet whereas it was the ideological facade rather than a totality that Marcuse reflected, dialectical naturalism can help us 
recover precisely what has been silenced through the identity of the cover-concepts imposed by reigning ideology.

Our age of ecological crises, has propelled dialectical analysis into a higher stage of truth. As posited by Bookchin, the pressing reality of global crises has obliged us to overcome the onesidedness of earlier conceptions of the dialectic which took for granted the necessity of the domination of nature in the 'progress' of history. Indeed, the great limitation with the Hegelian dialectical tradition - indeed German idealism - has always been its assumed separation between nature and Reason. ${ }^{12}$ The potentialities of true humanism lie, however, in the environmental conditions of its becoming. A liberated humankind, with its accompanying 'second nature', actualises itself through 'first nature' without reducing it into its own self-image: thus the dialectical understanding of the totality must, necessarily, be ecological. In the words of Adorno, "in its proper place, even epistemologically, the relationship of subject and object would lie in a peace achieved between human beings as well as between them and their Other. Peace is the state of differentiation without domination, with the differentiated participating in each other” (1998: s.2, 247). ${ }^{13}$ To give everything its proper place, does not have to issue in Heidegger's misbelief that such naming would lead to an all dominating agenda, yoking nature under 'the Idea,” and leading to the complete mastery of nature (see Heidegger, 1993). To give something its proper name, place and context, is to not identify it by a subjects own conception of it. As Adorno affirms, it can only come from thought in which neither subject nor object dominates the other. This requires dialectical thought to move beyond the conceptual identity imposed by the historical process, to cast off its earlier, ideological trappings that envisioned an impenetrable split between first and second natures, and which cast human history as sui generis rather than a product of a reciprocity between nature and reason. Ecological crises is the counterpoint to the thesis of 'one-dimensional society', not in any normative sense, but in that it transcends the closure of the dialectic under technical reality, creating conditions in which the negative can (re)emerge, rupturing the semblance of order of 'the real.' The contradictions of ecological crises today are so pervasive, so immediate, so obvious, as to spur negative thought toward the realisation of the contradiction of 'the real'. It is where capitalism can go no further. A dialectical ecologism offers this determinate negation of the environmental conditions of capitalism itself. Technological society may have deformed consciousness, subordinating thought to instrumental 
and technical interests, but the limits of the 'the real' push against ecological constraints that shatter the illusion of the permanency of the capitalist world order.

\section{References}

Abromeit, John. (2010). "Left Heideggerianism or Phenomenological Marxism? Reconsidering Herbert Marcuse’ Critical Theory of Technology,” Constellations, 17(1): 87-106.

Adorno, T.W. (1998). “On Subject and Object”, in Critical Models: Interventions and Catchwords, H.W. Pickford (Trans.), New York: Columbia University Press.

Adorno, T.W. (1998). "Resignation”, in Critical Models: Interventions and Catchwords, H.W. Pickford (Trans.), New York: Columbia University Press.

Adorno, T.W. (1998). “Why Still Philosophy?”, in Critical Models: Interventions and Catchwords, H.W. Pickford (Trans.), New York: Columbia University Press.

Anderson, Kevin B. Russell Rockwell. (2012). "Introduction”, in The Dunayevskaya-MarcuseFromm Correspondence, (K.B. Anderson and R. Rockwell (Eds.)), Maryland, MD: Lexington.

Biehl, Janet. Peter Staudenmaier. (1995). Ecofascism, Stirling: AK Press.

Bookchin, Murray. (1982). The Ecology of Freedom, Palo Alto, CA: Cheshire Books.

Bookchin, Murray. (1986). Post-Scarcity Anarchism, 2nd Edition, Montreal: Black Rose Books.

Bookchin, Murray. (1987). “Thinking Ecologically: A Dialectical Approach,” Our Generation, 18(2): 3-40.

Bookchin, Murray. (1990). "Recovering Evolution: A Reply to Eckersley and Fox," Environmental Ethics, 12(3): 253-274.

Bookchin, Murray. (1995a). "Postmodernist Nihilism,” in Re-Enchanting Humanity, New York: Cassell Press.

Bookchin, Murray. (1995b). Social Anarchism or Lifestyle Anarchism: An Unbridgeable Chasm, Stirling: AK Press.

Bookchin, Murray. (1995c) "Freedom and Necessity in Nature". Available at:http://theanarchistlibrary.org/library/murray-bookchin-freedom-and-necessity-in-nature-aproblem-in-ecological-ethics. Accessed on: 20th September, 2013.

Bookchin, Murray. (1996a). The Philosophy of Social Ecology: Essays on Dialectical Naturalism, Montreal: Black Rose Books. 
Bookchin, Murray. (1996b). Urbanization Without Cities: The Rise and Decline of Citizenship, Montreal: Black Rose Books.

Bookchin, Murray. (1999). "Freedom and Necessity in Nature” in The Murray Bookchin Reader (J. Biehl Ed.), Montreal: Black Rose Books.

Bookchin, Murray. (2009). "What is Ecology?” in Earthcare: An Anthology in Environmental Ethics (David Clowney \& Patricia Mosto Eds.), Lanham, MD: Rowman \& Littlefield.

Braun, Bruce (2008). "Nature and Culture”, in A Companion to Cultural Geography, J. Duncan, N.C. Johnson, R.H. Schein, London: Wiley.

Braun, Bruce. (2009). "Nature”, in A Companion to Environmental Geography, (N. Castree, D. Demeritt, D. Liverman, B. Rhoads Eds.), London: Wiley.

Braun, Bruce. Noel Castree (Eds.). (1998). Remaking Reality: Nature at the millennium, London: Routledge.

Buell, Lawrence. (1995). The Environmental Imagination: Thoreau, Nature Writing, and the Formation of American Culture. Cambridge, MA: Harvard University Press, 2.

Castree, Noel. (1996). "Birds, Mice and Geography: Marxisms and Dialectics”, Transactions of the Institute of British Geographers, New Series, 21(2): 342-362.

Castree, Noel. (2002). "False Antitheses? Marxism, nature and Actor-Networks", Antipode, 34(1): 111-146.

Clark, Butler. (2012). The Dialectical Method: A Treatise Hegel Never Wrote, New York: Humanity Books.

Dunayevskaya, Raya. Herbert Marcuse, Erich Fromm. (2012). The Dunayevskaya-MarcuseFromm Correspondence, 1954-1978: Dialogues on Hegel, Marx and Critical Theory, K.B. Anderson and R. Rockwell (Eds.), Maryland, MD: Lexington.

Engels, Frederick. Socialism: Utopian and Scientific, New York: International Publishers, 1972.

Fleming, Marie. (1988), The Geography of Freedom, Montreal: Black Rose Books.

Gordan, Uri. (2009). “Anarchism and the Politics of Technology”, The Journal of Labor \& Society, 12(3): 489-503.

Harvey, David. (1982). The limits to Capital. Oxford: Blackwell.

Harvey, David. (1997) Justice, Nature and the Geography of Difference, London: Wiley.

Hegel, G.W.F. (2004). Philosophy of Nature: Encyclopaedia of the Philosophical Sciences (1830), Part II (A.V. Miller Trans.), Oxford: Oxford University Press. 
Hegel, G.W.F. (2007). Lectures on the Philosophy of Spirit, 1827-1828 (trans. R. R. Williams), Oxford: Oxford University Press

Heidegger, Martin. (1993). "The Letter on Humanism” and The Question Concerning Technology”, in Basic Writings (F. Krell Ed.), San Francisco: Harper Collins, 1993.

Held, David. (1980). Introduction to Critical Theory: Horkheimer to Habermas, Berkeley, CA: University of California Press.

Horkheimer, Max. (1946). Eclipse of Reason, London: Simon \& Schuster.

Jones, A. (1999). "Dialectics and difference: against Harvey’s dialectical 'post-Marxism',” Progress in Human Geography, 23(4): 529-556.

Kellner, Douglas. (2005) "Radical Politics, Marcuse, and the New Left”, The New Left and the 1960s: Collected Papers of Herbert Marcuse, Vol. 3, D. Kellner (Ed.), London: Routledge.

Kovel, Joel. (1992).”Comment,” Capitalism Nature Socialism, 3(3): 40-42.

Leff, Enrique, (1998). "Murray Bookchin and the end of dialectical naturalism," Capitalism Nature Socialism, 9(4): 67-93.

Löwenthal, L. (1987), An Unmastered Past: The Autobiographical Reflections of Leo Löwenthal, (M. Jay ed., Berkley: University of California Press).

Marchand, Bernard. (1979). “Dialectics and Geography”, Philosophy in Geography, 20: 237267.

Marchand, Bernard. (1978). “A Dialectical Approach in Geography”, Geographical Analysis, 10(2): 105-119.

Marcuse, Herbert. (1948). “Existentialism: Remarks on Jean-Paul Sartre’s L’Être et le Néant”, Philosophy and Phenomenological Research, VIII(3), 1948, 311.

Marcuse, Herbert. (1965). “Socialist Humanism?” in E. Fromm (Ed.), Socialist Humanism: An international symposium, New York: Doubleday: 96-105.

Marcuse, Herbert. (1968). One-Dimensional Man, 7th Ed., Boston, MA: Beacon Press.

Marcuse, Herbert. (1973). Reason and Revolution, London: Routledge and Kegan Paul.

Marcuse, Herbert. (1982). “A Note on Dialectics” in The Essential Frankfurt School Reader, A. Arato, E. Gebhardt (Eds.), New York: Continuum: 444-451.

Marcuse, Herbert. (1992). "Ecology and the critique of modern society”, Capitalism Nature Socialism, 3(3). 
Marcuse, Herbert. (1998). "Some Social Implications of Modern Technology” in Technology, War and Fascism: Collected Papers of Herbert Marcuse, Vol. 1, D. Kellner (Ed.) London: Routledge, 1998.

Marcuse, Herbert. (2005). "Ecology and Revolution, in The New Left and the 1960s”, Collected Papers of Herbert Marcuse, Vol. 3, D. Kellner (Ed.), London: Routledge.

Marx, Karl. (1959). Economic and Philosophic Manuscripts of 1844, Moscow: Progress Publishers.

Marx, Karl. (1969). “Theses on Feuerbach.” In Marx-Engels Selected Works, vol. 1, translated by W. Lough, 13-15. Moscow: Progress Publishers.

Marx, Karl. Frederick Engels. (1975). “The German Ideology.” In Marx-Engels Collected Works, vol. 5, translated by Richard Dixon et al., 19-540. Moscow: Progress Publishers.

Ollman, Bertell. (1980) Alienation, 2nd Edition, Cambridge: Cambridge University Press.

Reclus, Elisée. (1892). The Earth and its Inhabitants: The Universal Geography, vol. 1. New York: Appleton.

Reclus, Elisée. (1911). “1895 letter to Mlle. Clara Koettlitz (April 12, 1895),” in Correspondence, Paris: Librarie Schleicher Frères.

Sheppard, Eric. (2008). “Geographic dialectics?,” Environmental and Planning A, 40: 26032612.

Springer, Simon. (2014). "War and pieces,” Space and Polity, 18(1): 85-96.

Whatmore, S. (1999). "Hybrid Geographies" in D. Massey, J. Allen, P. Sarre (Eds.), Human Geography Today, Cambridge: Polity Press. 
${ }^{1}$ For example, see Reclus' remarks on Autarky in the central Mediterranean (Reclus, 1890, Vol. I, 131) that, whilst being empirical, rely on a series of moralistic archetypes.

${ }^{2}$ We have decided to focus on those texts where Marcuse offers a concerted focus on his unique conception of dialectics. Regarding his dialectical method see (1982: 444-451). To explore the political implications of his dialectical approach, we turn to Marcuse's contribution in Fromm's edited volume Socialist Humanism (see 1965: 96-105). All quotes are taken from these two versions unless otherwise cited.

${ }^{3}$ Marcuse's political program would end with rather weak appeal to the Great Refusal located in the marginal groups. (Marcuse, 1968, 63-64).

${ }^{4}$ Waste is included alongside mental impoverishment, the threat of atomic destruction and brute force as these 'unresolved contradictions' in the status quo. It should be noted that Marcuse also views nature as suffering from 'conditions of alienation' alongside 'man' and that 'the consciousness of freedom' is the 'energy of nature and history’ (see Marcuse, 1982: 451).

${ }^{5}$ Rudolf Bahro's decline to a "spiritual fascism" and search for a "Green Adolf" is a sad reminder of what damage the lack of reflection can have for ecologism (see Biehl \& Staudenmaier, 1995: 48-50). We thank an anonymous reviewer for this point.

${ }^{6}$ This was a chauvinism not peculiar to the ideologues of capitalism but which also applied to many socialists of the past, particularly Proudhon and Marx (see Bookchin, 1996a: 15).

We thank an anonymous reviewer for raising this point.

${ }^{8}$ It must be pointed out that Marcuse's position on technology is nuanced. He was supportive of automation which he thought would liberate leisure time under capitalism (under certain conditions) and yet was also pessimistic regarding its liberatory potential in the conditions of capitalist modernity. This can be seen most evidently in his dialogue with Dunayevskaya (see Dunayevskaya, Marcuse, Fromm, 2012). On this see Abromeit (2010). We thank an anonymous reviewer for emphasising this point

${ }^{9}$ We thank our reviewers for raising these points.

${ }^{10}$ This resonates with, and develops further, the groundwork for a geography without hierarchy. See Simon Springer, "Human Geography without Hierarchy”, Progress in Human Geography, 38(3), 2014: 402-419.

${ }^{11}$ These technologies are said to include soar, wind, methane, and other sources of energy, the use of organic forms of agriculture, the design of humanly scaled, versatile industrial installations to meet regional needs of confederated municipalities. He also specifies the production of high-quality goods that can last for generations. However, it must also be pointed out that there is fundamental political dimension to these technological powers which are tied to direct democratic institutions and a confederation of ecocommunities (see Bookchin, 2009: 295).

${ }^{12}$ A key example is in Hegel's presentation of the Phenomenology in which it was the far lower stages of consciousness that were embedded in natural, un-reflexive, environment. Higher stages were associated with the severing of consciousness from the 'Umwelt'. Arguably, with this artificial separation a false notion of humanisation that abstracted humanity from its necessary relation with the latent potentialities of nature; and its doing so is bound up within the complex relation and movement of natural evolution itself.

${ }^{13}$ For a parallel account see Springer (2014) 